\title{
INHIBITION OF 3-HYDROXY-3-METHYLGLUTARYL-COENZYME A REDUCTASE ACTIVITY BY EXTRACTS OF GARCINIA XANTHOCHYMUS MESOCARP AND TOTAL FLAVONOID ASSAY QUANTIFICATION OF THE MOST ACTIVE EXTRACT
}

\author{
MEGAWATI, BERNA ELYA*, NURAINI PUSPITASARI \\ Department of Pharmacognosy and Phytochemistry, Faculty of Pharmacy, Universitas Indonesia, Depok, 16424, Indonesia. \\ Email: berna.elya@farmasi.ui.ac.id
}

Received: 20 June 2018, Revised and Accepted: 25 September 2018 and 31 October 2018

\section{ABSTRACT}

Objective: This study aims to determine the inhibitory activity of Garcinia xanthochymus mesocarp extracts against 3-hydroxy-3-methylglutaryl -coenzyme A (HMG-CoA) reductase.

Methods: G. xanthochymus mesocarp was macerated sequentially using n-hexane, ethyl acetate, and methanol. Phytochemical screening and quantification of total flavonoids were performed on the most active extract.

Results: Based on the tests, $\mathrm{n}$-hexane, ethyl acetate, and methanol extracts had inhibitory activities of $12.30 \pm 1.098 \%, 55.63 \pm 10.584 \%$, and $44.01 \pm 1.053 \%$, respectively. The results showed that the ethyl acetate is the most active extract, containing flavonoid, terpenoid, glycoside, and anthraquinone compounds. The amount of total flavonoid contained in ethyl acetate extract was $1.61 \%$ or $16.114 \mathrm{mg} Q \mathrm{E} / \mathrm{g}$ toward quercetin.

Conclusion: The n-hexane, ethyl acetate, and methanol extracts of G. xanthochymus have inhibitory actions against HMG-CoA reductase activity in vitro. Further research is still needed to strengthen this finding.

Keywords: Garcinia xanthochymus mesocarp, Total flavonoid, 3-Hydroxy-3-methylglutaryl-coenzyme A reductase, Sequential maceration, Phytochemical screening.

(C) 2018 The Authors. Published by Innovare Academic Sciences Pvt Ltd. This is an open access article under the CC BY license (http://creativecommons. org/licenses/by/4. 0/) DOI: http://dx.doi.org/10.22159/ijap.2018.v10s1.59

\section{INTRODUCTION}

Cholesterol is an amphiphilic lipid that is an essential structural component of the plasma membrane and the outer layer of plasma lipoproteins. It is synthesized in many tissues, is catalyzed by acetyl coenzyme A (acetyl-CoA), and is the precursor of all other steroids in the body, including corticosteroids, sex hormones, bile acids, and Vitamin D [1].

Hypercholesterolemia is characterized by elevated levels of low-density lipoprotein (LDL) or total cholesterol and low levels of high-density lipoprotein [2]. Hypercholesterolemia is a risk factor for non-infectious cardiovascular and metabolic diseases, such as atherosclerosis, metabolic syndrome, coronary heart disease, and stroke [3].

The drugs commonly used for the treatment of hypercholesterolemia include statins (simvastatin, atorvastatin, lovastatin, fluvastatin, rosuvastatin, and pravastatin), bile acid sequestrants (colestipol, colesevelam, and cholestyramine), nicotinic acid (niacin), and acid derivative fibrates: Peroxisome proliferator-activated receptors- $\alpha$ activators (clofibrate, gemfibrozil, fenofibrate, bezafibrate, and cyprofibrate), ezetimib, and fish oil supplements [4]. First-line therapy for hypercholesterolemia commonly uses statin drugs that inhibit 3-hydroxy-3-methylglutaryl-CoA (HMG-CoA) reductase, an enzyme that catalyzes the biosynthesis of cholesterol [1].

Plants of the Garcinia genus belong to the Clusiaceae or Guttiferae family. Currently, there are approximately 250 identified Garcinia species [5]. Garcinia xanthochymus is found mainly in Indonesia, especially in areas at altitudes of 1-500 m above sea level [6]. Some Garcinia species, such as Garcinia atroviridis and Garcinia cambogia, contain hydroxycitric acid (HCA), which has a hypolipidemic effect by decreasing lipogenesis and promoting glycogen progression, thereby suppressing the appetite [5].
HCA is a competitive inhibitor of adenosine $5^{\prime}$-triphosphate citrate lyase, an enzyme that catalyzes the extramitochondrial conversion of citrate to oxaloacetate and acetyl-CoA. Reduced availability of acetylCoA decreases the biosynthesis of fatty acids and cholesterol as well as lipogenesis [7]. According to Darwati and Supriyatna, the ethanol extract of G. xanthochymus bark can lower LDL levels in white mouse (Mus musculus) blood with extract levels below $100 \mathrm{mg} / \mathrm{bb}$ [8]. Based on chemotaxonomic considerations, G. xanthochymus is thought to contain HCA, as other Garcinia species can have similar effects.

G. xanthochymus contains quercetin [9], which is one of the most effective flavonoids to prevent LDL oxidation, as compared with other flavonoids such as myricetin, kaempferol, and morin [10]. Other compounds contained in G. xanthochymus include the biflavonoids morelloflavone and fukugetin [11]. According to Tuansulong et al., isolated morelloflavone compounds from Garcinia dulcis leaves can inhibit HMG-CoA reductase activity, which has a role in cholesterol biosynthesis, with an inhibition constant of $80.87 \pm 0.06 \mu \mathrm{M}$ against HMG-CoA and 103 $\pm 0.07 \mu \mathrm{M}$ against NADPH [12].

To gain knowledge of herbal plants in Indonesia, especially G. xanthochymus, researchers would like to know the ability of G. xanthochymus fruit extract to inhibit the activity of HMG-CoA reductase, an enzyme that has a role in cholesterol biosynthesis.

\section{METHODS}

\section{Extraction}

G. xanthochymus fruits were collected and wet-sorted washed with water, and dried. The fruits were cleaned, peeled, and cut into thin slices to speed up the drying process. The fruits were dried in an oven. The dried simplisia was then dry-sorted and grinded. Extraction was performed on simplisia powder by maceration using a multilevel extraction 
method from nonpolar (n-hexane), semipolar (ethyl acetate), and polar (methanol) solvents. After the maceration process, the solvents were evaporated with a rotary vacuum evaporator, and the extracts were placed in a water bath until they became a viscous extract. The obtained viscous extract was then weighed to calculate the percentage of yield, by dividing extract weight with simplisia weight $\times 100 \%$ [1]

\section{HMG-CoA reductase inhibition assay}

\section{Preparation of sample and standard solutions}

Samples of n-hexane extract, ethyl acetate extract, methanol extract, and quercetin (as positive control) were weighed as much as $\pm 10 \mathrm{mg}$, and then, five drops of dimethyl sulfoxide were added to support the dissolution. A phosphate buffer solution $\mathrm{pH} 7.4$ was adjusted to $10 \mathrm{~mL}$ volume to obtain a concentration of $1000 \mu \mathrm{g} / \mathrm{mL}$. The main solution was then diluted to a concentration of $100 \mu \mathrm{g} / \mathrm{mL}$. Dilution was performed with $10.0 \mathrm{~mL}$ of phosphate buffer $\mathrm{pH} 7.4$ [13]. Pravastatin solution used in the test had a concentration of $42.45 \mu \mathrm{g} / \mathrm{mL}$

\section{Determination of $I C_{50}$ pravastatin}

The pravastatin solution was used at $100 \mu \mathrm{M}$ or $42.45 \mu \mathrm{g} / \mathrm{mL}$. Pravastatin was diluted gradually from main solution using phosphate buffer $\mathrm{pH} 7.4$ to obtain concentrations of $21,22,10.61,5.30,2.65,1.32,0.66,0.33$, and $0.16 \mu \mathrm{g} / \mathrm{mL}$ or $50,000,25,000,12,500,6250,3125,1562.5,781.25$, and $390,625 \mathrm{nM}$ [14]. $1 \mu \mathrm{L}$ sample of each pravastatin concentration was then taken, and $181 \mu \mathrm{L}$ of buffer assay $\mathrm{pH} 7.4,4 \mu \mathrm{L}$ of NADPH, and 12 $\mu \mathrm{L}$ of HMG-CoA were added. Thereafter, $2 \mu \mathrm{L}$ of HMG-CoA reductase was added. The mixture was placed in a temperature-regulated microplate reader at $37^{\circ} \mathrm{C}$ and shaken for $10 \mathrm{~s}$, and the absorbance of the mixture was measured at $340 \mathrm{~nm}$ [15]. The test was carried out once. The percentage inhibition was calculated by dividing (A-B)-(C-D) with (A-B) $\times 100 \%$, where $\mathrm{A}=\Delta$ positive blank absorption, $\mathrm{B}=\Delta$ negative blank absorption, $\mathrm{C}=\Delta$ absorption sample, and $\mathrm{D}=\Delta$ sample blank absorption [13]. The percentage inhibition was then plotted against concentration where the X-axis was the concentration and the Y-axis was the percentage inhibition. After the linear regression equation $y=a+b x$ was obtained (Fig. 1), the value 50 was included in the equation substituting for the value $y$ so that the value of IC ${ }_{50}$ pravastatin would be obtained [14-16].

\section{Testing of sample and standard solutions}

Sample and standard solutions were each drawn as $1 \mu \mathrm{L}$, and then, $181 \mu \mathrm{L}$ of buffer assay pH 7.4, $4 \mu \mathrm{L}$ of NADPH, and $12 \mu \mathrm{L}$ of HMG-CoA were added.

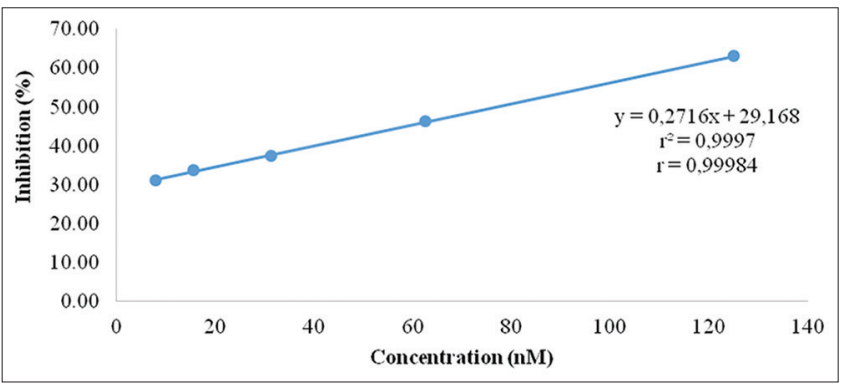

Fig. 1: $\mathrm{IC}_{50}$ pravastatin calibration curve
Thereafter, $2 \mu \mathrm{L}$ of HMG-CoA reductase solution was added. The mixture was placed in a temperature-regulated microplate reader at $37^{\circ} \mathrm{C}$ and shaken for $10 \mathrm{~s}$, and the absorbance of the mixture was measured at a wavelength of $340 \mathrm{~nm}$ (Table 1). Each test was performed 3 times [17].

The ability of the sample to inhibit HMG-CoA reductase can be determined from the percentage inhibition calculated by formula (2).

\section{Phytochemical screening}

Phytochemical screening was performed on the most active extract to determine the class of secondary metabolite compounds present in the extract. Identification of flavonoids using magnesium, concentrated hydrochloride acid, and amyl alcohol (Willstater's test) and elucidation using thin-layer chromatography (TLC) Silicagel $60 \mathrm{~F}_{254}$ as stationary phase and chloroform:acetone:formic acid (7:2:1) as mobile phase with $5 \%$ $\mathrm{AlCl}_{3}$ sprayed reagent and then observed under ultraviolet (UV) $366 \mathrm{~nm}$ light [16]. Positive control that was used is quercetin. Identification of alkaloids was done using Mayer's test, Borchardt's test, and Dragendorff's test [18] with boldine as a positive control. Identification of tannins was performed using $10 \%$ gelatine solution, $3 \%$ ferric chloride solution, and $10 \%$ sodium chloride $+10 \%$ gelatine solution [18] with Psidii Folium powder as positive control. Identification of saponins was performed using foam test [18] with Momordica Folium powder as a positive control. Identification of terpenoids and steroids was performed using Lieberman-Bouchard's test (acetic acid anhydrous:concentrated sulfuric acid [2:1]) [18] with $\beta$-sitosterol as a positive control. Identification of anthraquinones was done using Borntrager's test [18] with Phei Radix powder as a positive control. Identification of glycosides was performed using Molisch's test [18] with Stevia Folium as a positive control.

\section{Determination of total flavonoid content (TFC) by UV-visible spectrophotometry}

The standard used for measuring TFC was quercetin. Quercetin solutions were prepared at dilutions of $30,40,50,60,70$, and $80 \mu \mathrm{g} / \mathrm{mL}$ using $80 \%$ ethanol as solvent according to the standards of the Ministry of Health (2011), with modification [18]. Absorbance was measured at a maximum absorption wavelength of $434 \mathrm{~nm}$. Measurement of blanks without the addition of $\mathrm{AlCl}_{3}$ was performed for the correction factor. The absorption results were plotted and then put into the linear regression equation to obtain the equation $\mathrm{y}=\mathrm{a}+\mathrm{bx}$ [18]. The most active extract with a concentration of $4000 \mu \mathrm{g} / \mathrm{mL}$ was spiked with standard quercetin concentration $500 \mu \mathrm{g} / \mathrm{mL}$ using $80 \%$ ethanol. The solution was treated as described above. The absorbance was formulated into linear regression, and then, the content was calculated using formula: $\mathrm{TFC}=\left(\mathrm{R} \times 10^{-10} \times \mathrm{DF} \times \mathrm{V} \times 100\right) / \mathrm{W}$ to get total flavonoid percentage and $\mathrm{TFC}=\left(\mathrm{R} \times 10^{-10} \times \mathrm{DF} \times \mathrm{V}\right) / \mathrm{W}$ to get total flavonoid as gram quercetin equivalent per gram. Where $\mathrm{R}$ is the result obtained from standard curve $(\mu \mathrm{g} / \mathrm{mL}), D F$ is dilution factor, $V$ is volume of stock solution $(\mathrm{mL})$, and $\mathrm{W}$ is weight of extract used in sample test (g) [18].

\section{RESULTS AND DISCUSSION}

\section{Extraction}

The first step in handling G. xanthochymus fruit was wet sorting. After wet sorting, the fruit was washed with water and dried. The fruits were cleaned, peeled, and cut in thin slices to speed up the drying process.

Table 1: HMG-CoA reductase inhibition assay

\begin{tabular}{lllllll}
\hline Materials & \multicolumn{7}{l}{ Volume $(\boldsymbol{\mu L})$} & & \\
\cline { 2 - 7 } & Sample & Sample blank & Standard & Standard blank & Positive blank & Negative blank \\
\hline Extract solution & 1 & 1 & - & - & - & - \\
Pravastatin and quercetin & - & - & 1 & 1 & - & - \\
Buffer assay pH 7.4 & 181 & 199 & 181 & 199 & 182 & 184 \\
NADPH & 4 & - & 4 & - & 4 & 4 \\
HMG-CoA & 12 & - & 12 & - & 12 & - \\
HMG-CoA reductase & 2 & - & 2 & - & 2 & 200 \\
Final volume of well & 200 & 200 & 200 & 200 & 200 & 12 \\
\hline
\end{tabular}

HMG-CoA: 3-Hydroxy-3-methylglutaryl-coenzyme A 
The fruit was then dried. Drying aims to decrease the moisture content of the simplisia, thus preventing damage to materials and nutritious compounds caused by fungi or microbes and prevent enzymatic reactions in the sample due to the presence of water [19]. Several classes of compounds, such as flavonoid glycosides, can be degraded by enzyme activity when the plant is not in a dry condition [20]. The dried sample was then dry-sorted and pollinated in a blender. The pollination of sample was intended to facilitate the absorption of the solvent during extraction by increasing the surface area of the sample so that the penetration of solvent into the sample cell membrane would be easier [21]

\section{Simplisia extraction}

The blended simplified powder was extracted by a multilevel maceration method using three different types of solvents: Non-polar (n-hexane), semipolar (ethyl acetate), and polar (methanol). The use of solvents with stratified polarities from non-polar to polar separates the compounds based on their polarity. The solvent sequence for extraction began with n-hexane, a solvent with low polarity. n-Hexane was used to extract nonpolar compounds, such as waxes, oils, and fats [20]. The next solvent used was ethyl acetate, which was chosen because of its semipolar characterization. Ethyl acetate extracts semipolar compounds, such as flavonoid aglycone group (isoflavones, flavanones, methylated flavones, and flavonols) [20]. Ethyl acetate also extracts terpenoid, alkaloid, and glycoside compounds [22]. The last solvent used was methanol, which has high polarity. Methanol extracts polar glycosides and more polar aglycones [20]. Methanol also extracts quaternary alkaloids, carotenoids, tannins, and amino acids [22]. Ethyl acetate and methanol were used to extract phenolic compounds [20]. The weight of the viscous extract and the percentage value of the yield of each solvent are shown in Table 2 .

\section{HMG-CoA reductase inhibition assay}

HMG-CoA reductase inhibition assay was performed in vitro using the HMG-CoA Reductase Assay Kit CS1090 (Sigma Aldrich, USA). The kit contains HMG-CoA reductase enzyme (concentration $0.50-0.70 \mathrm{mg}$ protein/mL), HMG-CoA, NADPH, pravastatin substrate as positive control, and $100 \mathrm{mM}$ pH 7.4 potassium phosphate buffer assay. The HMG-CoA reductase present in the kit is a recombinant human enzyme of GST fusion protein expressed on Escherichia coli [17].

\section{Determination of $I C_{50}$ pravastatin}

The pravastatin used for testing had a concentration of $100 \mu \mathrm{M}$ or $42.45 \mu \mathrm{g} / \mathrm{mL}$ [17]. The calibration curve for $\mathrm{IC}_{50}$ pravastatin is shown in Fig. 1. $\mathrm{IC}_{50}$ pravastatin obtained from the test was $76.701 \mathrm{nM}$ or $0.0325 \mu \mathrm{g} / \mathrm{mL}$, while the $\mathrm{IC}_{50}$ pravastatin values obtained from the literature using the same methods were $66.1 \mathrm{nM}$ [23], $70.25 \mathrm{nM}$ [24], and $87.76 \mathrm{nM}$ [14]. The differences in test results are thought to be due to differences in the conditions of preparation, testing, and instruments affecting the enzyme absorption results.

\section{Sample and standard assay}

The HMG-CoA reductase inhibition assay was performed with n-hexane, ethyl acetate, and methanol extracts and with pravastatin and quercetin as standards. According to the test results (Fig. 2), the ethyl acetate extract had the highest percentage of inhibition of HMG-CoA reductase, with an average of $55.63 \% \pm 10.58 \%$.

The methanol extract had the second highest percentage of inhibition, at $44.01 \pm 1.053 \%$. The $\mathrm{n}$-hexane extract had the lowest average inhibition rate, at $12.30 \pm 1.098 \%$. In this test, pravastatin, a semisynthetic drug

Table 2: Yield of the extract

\begin{tabular}{lll}
\hline No. & Solvent & Yield of extract (\%) \\
\hline 1 & n-hexane & 3.80 \\
2 & Ethyl acetate & 18.71 \\
3 & Methanol & 24.50 \\
\hline
\end{tabular}

compound with an average percentage of inhibition of $96.80 \pm 1.315 \%$, was used as a positive control. Quercetin was also used as a positive control of the marker compound in plants, with an average percentage of inhibition of $81.72 \pm 12.204 \%$. Differences in inhibitory activity between samples may be due to differences in the content of secondary metabolites that are extracted during the extraction due to the use of different solvents [13].

Feng et al. (2012) showed that G. xanthochymus contained quercetin compounds [9]. This finding was confirmed by the TLC test (Fig. 3), which showed that ethyl acetate extract of $G$. xanthochymus fruit appears to contain quercetin or similar compounds because it has the same spot size, color, and $\mathrm{Rf}$ value $(\mathrm{Rx}=1)$ as quercetin. Quercetin is more effective at preventing LDL oxidation than are other flavonoids, such as myricetin, kaempferol, and morin. LDL oxidation is associated with an increased risk of atherosclerosis [10]. Quercetin 0-glycosides, such as isoquercitrin and quercetin-gentiobioside, were reported to have inhibitory activity against HMG-CoA reductase, with $\mathrm{IC}_{50}$ values of 80.6 and $50.6 \mu \mathrm{M}$, respectively [25].

In $G$. xanthochymus fruits, there are biflavonoid compounds, namely fukugetin or morelloflavone, consisting of naringenin and luteolin [11], in which the ethyl acetate solvent is estimated to attract flavonoid aglycone groups, such as flavanone, methylated flavone, and flavonol [20]. Morelloflavone inhibits the activity of HMG-CoA reductase by binding with a hydrophobic portion of the active site or enzyme subunit. The cyclic B ring structure in morelloflavone can bind to the enzyme because it resembles the pyran ring in HMG-CoA and statin groups to prevent enzymes binding to the substrate. Morelloflavone is competitive against HMG-CoA and non-competitive against NADPH [12].

The ethyl acetate extract of $G$. xanthochymus fruit also contains terpenoid compounds, which according to Sashidhara et al. terpenoid compounds, that is, dihydro (16-oxocleroda-3,13 (14) E-dien-15-oat

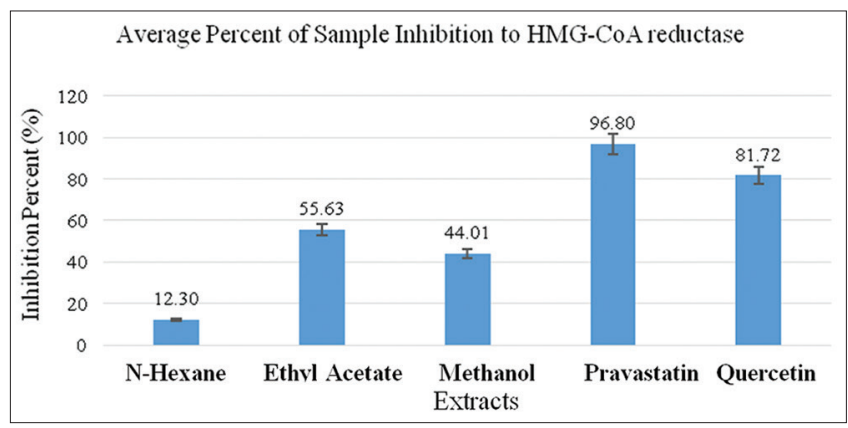

Fig. 2: Percentage of the inhibition of 3-hydroxy-3-methylglutarylcoenzyme A reductase by Garcinia xanthochymus extracts and positive controls

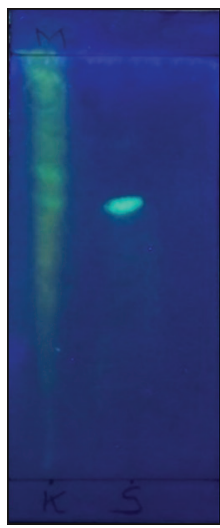

Stationary phase: Silica gel $60 \mathrm{~F}_{254}$

Mobile phase: chloroform-acetone-formic acid ( $7: 2: 1)$ using $5 \% \mathrm{AlCl}_{3}$ as spray reagent and observed at 366 $\mathrm{nm}$.

Fig. 3: Thin-layer chromatography test results of ethyl acetate extract of Garcinia xanthochymus fruit 
acid) isolation results from Polyalthia longifolia have similarities with lovastatin structure which is a statin drug group with a percentage of inhibition of $78.03 \%$ at concentrations of $100 \mu \mathrm{M}$ and $\mathrm{IC}_{50}$ to $\mathrm{HMG}-\mathrm{CoA}$ reductase of $30.2 \mu \mathrm{M}$ for diterpene and $20.1 \mu \mathrm{M}$ for lovastatin [26]

\section{Phytochemical screening}

Phytochemical screening was performed on the ethyl acetate extract of G. xanthochymus fruit, which has the highest inhibitory activity against HMG-CoA reductase. Based on the test results, the extract was suspected to contain flavonoids, terpenoids, glycosides, and anthraquinones. In the flavonoid test, the ethyl acetate extract of $G$. xanthochymus fruit turned orange when concentrated magnesium- $\mathrm{HCl}$ powder was added and then withdrawn with amyl alcohol, indicating that the extract contained flavonoid compounds. Magnesium- $\mathrm{HCl}$ powder was added to reduce sugar bonding so that amyl alcohol could attract the flavonoid aglycone [27]. The extractalso produced greenish-yellowish fluorescence in filter paper when observed under $366 \mathrm{~nm}$ UV light, although the fluorescence was not as positive as that with a positive control signifying an extract containing flavonoids. The last flavonoid test of the extract used TLC silica gel $60 \mathrm{~F}_{254}$ plate with chloroform:acetone:formic acid (7:2:1). The diluted extract solution was then dried and sprayed with $\mathrm{AlCl}_{3} 5 \%$. The plates were then observed under $366 \mathrm{~nm}$ UV light. The extract yielded greenish-yellowish fluorescence when observed under UV light. The chromatogram that was sprayed with an $\mathrm{AlCl}_{3}$ spotting agent will react with the keto group on $\mathrm{C}-4$ and $\mathrm{OH}$ groups in $\mathrm{C}-5$, and the $\mathrm{OH}$ group was orthodominated in flavone or flavonol compounds to form a greenish-yellow compound complex [28]. Tests using such TLC plates also aim to determine whether there are compounds of quercetin in the extract by comparing quercetin patches with sample spots [29]. Quercetin as a comparator for the extract shows greenish-yellow spots with an Rf value of 0.657 . Ethyl acetate extract also shows a greenishyellow stain with an Rf value of 0.657 . The test compound and the comparator are the same if the spots are identical, the size of the spots is almost the same, and the $\mathrm{Rx}$ value is 1 .

In the terpenoid test, the ethyl acetate extract of $G$. xanthochymus fruit produced a brown color when the Liebermann-Burchard reagent (acetic acid anhydride: concentrated sulfuric acid 2:1) was added, so it can be concluded that the extract contained a terpenoid compound. The reaction that occurs in the terpenoid test is acetylation of the hydroxyl group by anhydrous acetic acid so that the acetyl group is loosened and a double bond is formed. The hydrogen groups and their electrons are then released, resulting in movement of a double bond. This compound undergoes a resonance that acts as an electrophile or carbocation. Carbocation attacks cause electrophilic addition followed by hydrogen release. The hydrogen group and the electrons are then removed so that the compound undergoes a conjugate extension with the appearance of a brown color [30]. The color difference of the extract test results with the controls because the used control was steroid group that forms green color when added by Liebermann-Burchard reagent while in the extract contains terpenoid and not steroid.

In the anthraquinone test, the ethyl acetate extract of $G$. xanthochymus fruit produced a yellow color in the filtrate layer when shaken with benzene $\mathrm{P}$. The filtrate also produced a red color when $\mathrm{NaOH} 2 \mathrm{~N}$ was added and was colorless in the benzene layer so that it can be concluded that the extract contained anthraquinone compounds. Benzene was added to extract anthraquinone, while an added base, which in this test was $\mathrm{NaOH} 2 \mathrm{~N}$, will react with anthraquinone to produce red, violet, green, or purple colors [31].

In the glycoside test, ethyl acetate extract of $G$. xanthochymus fruit produced a purple ring at the liquid border when concentrated sulfuric acid was added to a mixture of extract solution and Molisch's reagent. Therefore, it can be concluded that there are carbohydrate glycoside compounds in the extract. The purple ring is produced by the formation of a complex between naphthol and the result of glucose reduction, i.e., 5-(hydroxymethyl) furfural [32].

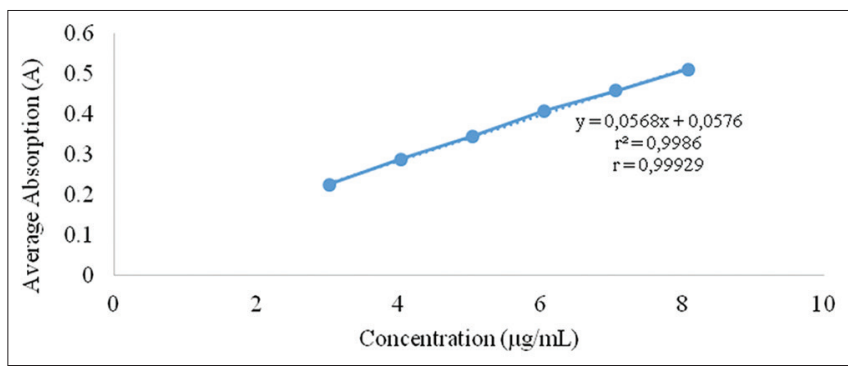

Fig. 4: Quercetin calibration curve

\section{Determination of TFC}

Before the determination of TFC in ethyl acetate extract of G. xanthochymus fruit, the extract was tested qualitatively against flavonoid compounds to determine whether there was a flavonoid compound in the extract. The results showed that the extract contained flavonoids, and therefore their content could be determined. The method used for determining TFC was the $\mathrm{AlCl}_{3}$ colorimetric method using quercetin as the standard. Quercetin was chosen as the standard because some studies mentioned that quercetin was a suitable standard for determining TFC in plant extract samples [33]. Standard quercetin solutions with final concentrations of 3.03, 4.04, 5.05, 6.06, 7.07, and $8.08 \mu \mathrm{g} / \mathrm{mL}$ were measured at a wavelength of $434 \mathrm{~nm}$. The absorption results were plotted into the regression equation so that the equation $\mathrm{y}=0.0568 \mathrm{x}+0.0576$ with $\mathrm{r}=0.99929$ was obtained (Fig. 4).

Quercetin was also chosen because it belongs to the flavonoid group, with keto groups in C-4 and a hydroxy group on neighboring C-3 or C-5 atoms, and is therefore suitable for the standard method of $\mathrm{AlCl}_{3}$ colorimetry [34]. The $\mathrm{AlCl}_{3}$ colorimetric method was used to determine the flavonoid counts of the flavon and flavonol classes because only those groups react to form complexes with $\mathrm{AlCl}_{3}$ [35].

Ethyl acetate extract of $G$. xanthochymus fruit had a TFC of $1.61 \%$ or $16.11 \mathrm{mg}$ QE/g. In the colorimetric method for the determination of TFC, $1 \mathrm{M}$ sodium acetate and $\mathrm{AlCl}_{3}$ were used as reagents. Sodium acetate can ionize the most acidic hydroxy groups in flavonoids to detect the presence of free 7-hydroxyl groups in flavones and flavonols. The addition of sodium acetate to the test can also maintain the wavelength of sample absorption in the visible region [36]. The addition of $\mathrm{AlCl}_{3}$ leads to the formation of stable acid complexes with the $\mathrm{C}-4$ keto groups and the hydroxyl groups of $\mathrm{C}-3$ or $\mathrm{C}-5$ in flavones and flavonols. $\mathrm{AlCl}_{3}$ also causes the formation of labile acid complexes with orthohydroxyl groups in the $\mathrm{A}$ and $\mathrm{B}$ flavonoid rings [36]. Addition of $\mathrm{AlCl}_{3}$ may cause a bathochromic shift in the absorption, resulting in an increase in the intensity of the yellow color [37].

\section{CONCLUSION}

The n-hexane, ethyl acetate, and methanol extracts of G. xanthochymus have inhibitory actions against HMG-CoA reductase activity in vitro with the highest inhibitory activity is ethyl acetate extract. The ethyl acetate extract contains flavonoids, terpenoids, glycosides, and anthraquinones with total flavonoid $1.61 \%$ or $16.11 \mathrm{mg} \mathrm{QE} / \mathrm{g}$ toward quercetin.

\section{ACKNOWLEDGMENTS}

All authors acknowledge Universitas Indonesia for support and PITTA Research Grants 2017.

\section{CONFLICTS OF INTEREST}

Authors declare no conflicts of interest in this research.

\section{REFERENCES}

1. Murray RK, Granner DK, dan Rodwell VW. In: Pendit BU, editor. Harper's Illustrated Biochemistry. $27^{\text {th }}$ ed. New York: McGraw-Hill; 2009. 
2. Goodman LS, Gilman A. The Pharmacological Basis of Therapeutics. $11^{\text {th }}$ ed. New York: McGraw-Hill; 2006.

3. Health Ministry's Health Research and Development Agency. Basic Health Research 2013. Jakarta: Ministry of Health, Republic of Indoensia; 2013

4. Wells BG, Dipiro JT, Schwinghammer TL, Dipiro CV. Pharmacotherapy Handbook. $9^{\text {th }}$ ed. United States: McGraw-Hill Education; 2015.

5. Lim TK. Fruits. In: Edible Medicinal and Non-Medicinal Plants. Vol. 2. New York: Springer; 2012.

6. P.T. Eisai Indonesia. Index of Medicinal Herbs in Indonesia. Jakarta: PT Eisai Indonesia; 1986

7. Jena BS, Jayaprakasha GK, Singh RP, Sakariah KK. Chemistry and biochemistry of (-)-hydroxycitric acid from Garcinia. J Agric Food Chem 2002;50:10-22.

8. Darwati, Supriyatna GP. Test Activity Decrease Cholesterol from Ethanol Extract of Garcinia xanthochymus on Mus musculus. National Chemistry Proceeding III PMIPA FKIP UNS; 2011. p. 628-33.

9. Feng J, Zhan-lin L, Sheng-Li N, Hui-Ming H. Studies on the chemical constituents of the barks of Garcinia xanthochymus. Chin J Med Chem 2012;2012:6.

10. Zhu QY, Huang Y, Chen ZY. Interaction between flavonoids and alpha-tocopherol in human low density lipoprotein. J Nutr Biochem 2000;11:14-21.

11. Baggett S, Protiva P, Mazzola EP, Yang H, Ressler ET, Basile MJ, et al. Bioactive benzophenones from Garcinia xanthochymus fruits. J Nat Prod 2005;68:354-60.

12. Tuansulong KA, Hutadilok-Towatana N, Mahabusarakam W, Pinkaew D, Fujise K. Morelloflavone from Garcinia dulcis as a novel biflavonoid inhibitor of HMG-coA reductase. Phytother Res 2011;25:424-8.

13. Hasanah Q, Faridah DN, Andrianto D. Inhibition activity of HMG-CoA reductase by rice brain extract and its fractions as anticholesterolemia in vitro study. Pharm Chem 2016;8:1-5.

14. Hafidz KA. Inhibitory Activity Test on HMG CoA Reduktase and Determination of Resveratrol Levels from Melinjo Seed Extracts (Gnetum gnemon L.). Thesis. Jakarta: Universitas Indonesia; 2016.

15. Winata HS, Rosidah R, Sitorus P. Assessment of anti-inflammatory activity of ethanolic extract of asam kandis (Garcinia xanthochymus hook. F.EX T. Anderson) fruit. Asian J Pharm Clin Res 2018;11:81-3.

16. Gogoi N, Gogoi A, Neog B. Free radical scavenging activities of Garcina xanthochymus hook. F. and Garcinia Lanceaefolia Roxb. Using various in vitro assay models. Asian J Pharm Clin Res 2015;8:138-41.

17. Aldrich S. HMG-CoA Reductase Assay Kit Technical Bulletin. USA: Sigma Aldrich; 2012

18. Department of Health Republic of Indonesia. Supplement II Farmacope Herbal Indonesia. $1^{\text {st }}$ ed. Jakarta: Department of Health Republic of Indonesia; 2011a.

19. World Health Organization. WHO Guidelines on Good Agricultural and Collection Practices (GACP) for Medicinal Plants. Genewa: World Health Organization; 2003.

20. Andersen ØM, dan Markham KR. Flavonoids: Chemistry, Biochemistry, and Applications. Boca Raton: CRC Press; 2006.

21. Perdana F. Isolation of phenolic compounds from methanol extract of tamarind leaves (Garcinia xanthochymus Hook.). J Farmako Bahari $2015 ; 6: 17-27$

22. Harborne JB. Phytochemical Method. Kosasih Padmawinata and Iwang
Soediro. Bandung: Institute Technology Bandung; 1987.

23. Perchellet JP, Perchellet EM, Crow KR, Buszek KR, Brown N, Ellappan S, et al. Novel synthetic inhibitors of 3-hydroxy-3methylglutaryl-coenzyme A (HMG-coA) reductase activity that inhibit tumor cell proliferation and are structurally unrelated to existing statins. Int J Mol Med 2009;24:633-43.

24. Iqbal D, Khan MS, Khan A, Khan MS, Ahmad S, Srivastava AK, et al. In vitro screening for $\beta$-hydroxy- $\beta$-methylglutaryl-CoA reductase inhibitory and antioxidant activity of sequentially extracted fractions of Ficus palmata forsk. BioMed Res Int 2014;2014:1-10.

25. Kwon EK, Lee DY, Lee H, Kim DO, Baek NI, Kim YE, et al. Flavonoids from the buds of Rosa damascena inhibit the activity of 3-hydroxy3-methylglutaryl-coenzyme a reductase and angiotensin I-converting enzyme. J Agric Food Chem 2010;58:882-6.

26. Sashidhara KV, Singh SP, Srivastava A, Puri A, Chhonker YS, Bhatta RS, et al. Discovery of a new class of HMG-coA reductase inhibitor from Polyalthia longifolia as potential lipid lowering agent. Eur J Med Chem 2011;46:5206-11

27. Mustapa MA. Analysis of the Levels of Flavonoid Compounds of Methanol Extract of Lamtoro Leaves (Leucaena leucocephala) with Spectrophotometry Method UV-Vis. Thesis. Gorontalo: Universitas Negeri Gorontalo; 2014

28. Anwar K, Triyasmono L. Total phenolic content, total flavonoids, and antioxidant activity of noni fruit ethanol extract (Morinda citrifolia L.). J Pharm Sci 2016;3:83-92

29. Department of Health Republic of Indonesia. Farmacope Herbal Indonesia. $1^{\text {th }}$ ed. Jakarta: Department of Health Republic of Indonesia; 2011.

30. Setyowati WA, Ariani SR, Ashadi, Mulyani B, Rahmawati CP. Phytochemical screening and identification of major components of skin durian methanol extract (Durio zibethinus Murr.) varieties petruk. Natl chem Educ chem 2014;6:271-80.

31. Marliana SD, Suryanti V, Suyono. Phytochemical screening and chromatographic analysis of thin layer chemical components of squash gourd (sechium edule Jacq. Swartz.) in etanol extract. Biofarmasi 2005;3:26-31

32. Department of Health Republic of Indonesia. Medics Material. $6^{\text {th }}$ ed. Jakarta: Department of Health Republic of Indonesia; 1995.

33. Bhaigyabati TH, Devi PG, Bag GC. Total flavonoid content and antioxidant activity of aqueous rhizome extract of three Hedychium species of Manipur valley. Res J Pharm Biol Chem Sci 2014;5:970-6.

34. Desmiaty Y, Ratnawati J, Andini P. Determination of Total Flavonoid amount of Ethanol Extract of Red Fruit Leaves (Pandanus conoideus Lamk.) with Complementary Colorimetry, 1-8. National Seminar Proceedings POKJANAS TOI XXXVI; 2009

35. Rohini RM, Amit KD. Determination of lupeol., B-sitosterol and quercetin from ethyl acetate extract of Rhizophora mucronata bark by HPTLC technique. Asian J Pharm Clin Res 2011;4:103-5.

36. Chang C, Yang M, Wen H, Chern J. Estimation of total flavonoida content in propolis by two complementary colorimetric methods. J Food Drug Anal 2002;10:178-82.

37. Ahmad AR, Ratulangi SA, Abdul M. Determination of phenolic and total flavonoid content of methanol and fruit extracts (Etlingera elatior Jack). Pharm Sci Res 2015;2:1-10 